\title{
Poverty and Economic Polarization Among Children in Racial Minority and Immigrant Families
}

\author{
Daniel T. Lichter, Zhenchao Qian, \\ and Martha L. Crowley
}

$\mathbf{R}$ ecent trends in child poverty and inequality can only be fully understood in light of America's growing racial and ethnic diversity, fueled largely by the massive new immigration from Latin America and Asia. Indeed, the racial and ethnic fabric of the United States changed substantially during the last half of the 20th century. In 1950, for example, the U.S. Census Bureau reported that 134 million, or nearly $90 \%$ of America's 151 million people, were white. ${ }^{1}$ Blacks accounted for significantly more than $90 \%$ of the remaining nonwhite population (Gibson \& Jung, 2002). Questions about race and inequality were considered almost exclusively in terms of black and white. The situation had changed considerably by the turn of the 21 st century. Today, whites represent only $75 \%$ of America's population. Hispanics are now America's largest racial or ethnic minorityat $12.5 \%$-whereas the black population has remained relatively constant at $10 \%$ to
$12 \%$ since $1950 .^{2} \mathrm{~A}$ diverse Asian population accounts for about $4 \%$ of the U.S. population and comprises many different nationalities (Barnes \& Bennett, 2002; Grieco \& Cassady, 2001). Increasingly, minority population shares are especially apparent among children. Overall, in 2000, nearly two of five children were members of racial/ethnic minority groups or immigrant families (Hernandez, 2004).

Growing diversity raises the need to better monitor the changing economic incorporation of minority children, including immigrants, into American society. Recent trends among children also raise important new questions about racial stratification and persistent inequality in America's future. Unfortunately, one study after another has shown that poor children have a high probability of becoming poor adults because poverty is reproduced from one generation to the next (Gottschalk, 1997; Lichter, 1997). Racial and ethnic 
minorities also will represent a growing share of the population relative to America's aging white population. Thus, high rates of child poverty today, especially among the children of racial minorities and immigrants, may provide a portent of America's future-one characterized by growing racial and economic inequality. ${ }^{3}$ It is more important than ever to evaluate the changing economic circumstances of America's increasingly diverse population of children. Such is our purpose.

In this chapter, we have two primary goals. First, we document changes in child poverty rates between 1990 and 2000 for different racial and ethnic groups. Like other studies (Lichter \& Landale, 1995; Manning \& Brown, 2006), we emphasize the role of family structure, including the rise in cohabitation, and increasing maternal employment in shaping children's economic circumstances. But we also highlight the new patterns of racial and ethnic variation in children's recent experiences. Second, unlike most previous studies, we evaluate children's changing location in the family income distribution (see Lichter \& Eggebeen, 1993). Specifically, is there a growing gap between rich and poor children, and has this gap been reinforced by growing racial diversity and immigration over the past decade? These dual objectives are addressed using data from the $5 \%$ samples of 1990 and 2000 Public Use Microdata Samples from the U.S. Decennial Censuses.

\section{CHILD POVERTY AND RACIAL INEQUALITY}

According to Bianchi (1999), poverty in America has become increasingly "juvenilized" during the past three decades. In the 1960 s, child poverty rates were only about three-fifths as high as poverty rates among the elderly, but they were more than $80 \%$ higher in the early 1990s. ${ }^{4}$ The economic roller coaster of the 1990s and early 2000s has also ushered in a new period of uncertainty in the family and economic lives of America's children (Lichter \& Qian, 2004; Thomas \& Sawhill, 2005). Poverty rates among children residing in the United States peaked during the 1993 recession, but subsequently declined by the end of the 1990s to their lowest levels $(17.1 \%)$ in 20 years (U.S. Census Bureau, 2007a). Although this is welcome news, these national changes reflect the balance of poverty trends across a variety of population subgroups, including children in America's minority and immigrant families (Lichter \& Crowley, 2004; Van Hook, Brown, \& Kwenda, 2004). As such, they may conceal divergence among subgroups of children, some of which may not have benefited from the economic largesse of the 1990s.

Effective public policy aimed at reducing child poverty depends on improving our understanding of the forces underlying recent trends and racial differentials in child poverty. An Urban Institute report claimed that the 1996 welfare reform bill would doom an additional 1 million children to poverty (Zedlewski, Clark, Meier, \& Watson, 1996). Clearly, these early forecasts have not materialized. Even the most prescient observers could not have anticipated the swift increase in employment rates among single mothers, from $60 \%$ in 1994 to $72 \%$ in 1999 (Moffitt, 2002). Recent estimates suggest that rising maternal employment, which some experts attribute to state "work first" welfare programs, may have accounted for as much as $50 \%$ of the post-1996 decline in poverty among children living in female-headed families (Lichter \& Crowley, 2004). A burgeoning economy also played a large role. For example, Iceland (2003) and Gunderson and Ziliak (2004) showed that macroeconomic growth was strongly linked to declines in poverty during the 1990 s. On the whole, it seems that economic growth, including rising 
maternal employment, has played a large role in shaping children's shifting economic circumstances. ${ }^{5}$

Changing family structure and child poverty have been inextricably linked during the past 40 years. In the 1960 s, for example, most poor children lived with two parents who were married. By the end of the 1990s, $57 \%$ of poor children lived in female-headed families (U.S. Census Bureau, 2007b). Eggebeen and Lichter (1991) showed that about one-half of the rise in child poverty during the 1980s was caused by shifts in the child population from married-couple families to "high risk" female-headed families (cf. Cancian \& Reed, 2002; Lerman, 1996; Thomas \& Sawhill, 2002). The good news is that changes in family structure slowed significantly in the 1990s and were no longer associated with increases in poverty, even among children (Iceland, 2003; Lichter \& Crowley, 2004). One policy implication is that any further reductions in child poverty may require more government, community, and faith-based efforts to promote marriage and strengthen fragile families. Indeed, the current Republican administration, through the Administration for Children and Families (ACF), has sponsored a "Healthy Marriage Initiative" that aims to stem unwed childbearing and help sustain healthy marital relationships, mostly through marriage education (e.g., relationship skills training) and counseling.

The negative economic implications of single parenthood and positive implications of maternal work in the 1990s for children's economic well-being have been unmistakable. Whether these patterns are also found among various racial and ethnic minorities or immigrant groups, however, is less clear. Despite declines in child poverty in the 1990s, large racial and ethnic differences persist while racial diversity in America has rapidly grown (Lichter, Qian, \& Crowley, 2005; Manning \& Brown, 2006). The children of minority and immigrant families have been affected in uncertain ways by long-term increases in maternal employment and family change. For example, the late 1990s brought especially large employment increases among African American single mothers, apparently in response to work-based welfare reform (Moffitt, 2002). On the other hand, inequality between blacks and whites, as measured by differences in child poverty, has been exacerbated over recent decades by growing racial differences in family structure (Eggebeen \& Lichter, 1991). Unlike the situation for Americanborn blacks, differences in family structure accounted for only a small part of large Hispanic-white difference in child poverty during the 1980s. For Hispanic children, and especially Mexican-origin children, a large part of the poverty gap stems from differences in maternal employment (i.e., Hispanic mothers have lower employment rates).

Far less is known about the demographic and economic foundations of changing poverty rates among children in immigrant families, or immigrant-native differences (Crowley, Lichter, \& Qian, 2006; Jensen \& Chitose, 1994). A recent study by Hernandez (2004) showed that the poverty rate for immigrants was 50\% higher in 1999 than was poverty among the native-born $(21 \%$ vs. $14 \%$ ). However, poverty rates among firstand second-generation immigrants declined slightly in the 1990s, after doubling (from $11.6 \%$ to $22.2 \%$ ) during the preceding two decades (Van Hook et al., 2004). This study also reported that roughly one-half of the increase in immigrant poverty between 1969 and 1999 was attributable to changing economic conditions (as measured by parental work patterns). Child poverty rates in 1999 varied from a low of $9.5 \%$ among nonHispanic whites to $32.9 \%$ among Mexicans. In 2000, the poverty rate for immigrants who entered the United States before 1970 was $8.3 \%$. Rates for those arriving in the $1970 \mathrm{~s}$, $1980 \mathrm{~s}$, and $1990 \mathrm{~s}$ were $11.5 \%, 15.2 \%$, and $23.5 \%$, respectively (Lichter \& Crowley, 
2002). These differences in poverty reflect the fact that recently arrived immigrants tend to be of childbearing age, are poorly educated, have fewer English language skills, and often lack the job skills necessary to avoid poverty. Measured poverty may veil even greater economic hardship if unsuccessful immigrants have returned to their countries of origin.

The typically positive interpretation given to widespread declines in child poverty during the 1990s, however, must be interpreted in light of America's rising overall standard of living (Eggebeen \& Lichter, 1991; Rainwater \& Smeeding, 2004). By definition, poverty income thresholds, if measured in constant dollars, have remained essentially unchanged since they were first introduced in the mid-1960s. Median family income, on the other hand, has increased substantially. Consequently, if compared with the national standard of living, the poor have fallen more deeply into poverty as the gap between average incomes of America's poor people and its middle-class and affluent people has grown (Iceland, 2003). In 1966, for example, the average income of the poorest one-fifth of U.S. families expressed as a ratio to mean family income was only .28. In other words, the income of poor families was $72 \%$ lower than the average U.S. family income. By 2001, the income of the poorest segment of the population was $79 \%$ lower. During that time, the mean income of the richest one-fifth of U.S. families rose dramatically in relation to the average family income-their income was $103 \%$ higher in 1966 , and $139 \%$ higher in 2001 (see historical income figures in U.S. Census Bureau, 2007c, 2007d).

As the incomes of America's wealthiest families have burgeoned and average family incomes have grown, the U.S. government's poverty income thresholds have not kept pace. In 1980, for example, the median family income was 2.5 times greater than the poverty income threshold for a family of four. By 2001, this figure had climbed to 2.8, indicating that the increases in absolute poverty thresholds have lagged behind the growth in family income during the past two decades.

One implication is that America's children may be on two different tracks into adulthood (e.g., Lichter \& Eggebeen, 1993; McLanahan, 2004). One track is made up of poor and economically disadvantaged children living with single or divorced mothers or in two-parent working families struggling to make ends meet in a changing global economy. Many historically disadvantaged racial minorities and the "new" immigrant children fall into this population. A second track-so-called "cornucopia kids"-are living with two highly educated working parents. A disproportionately large majority of such children are white. Rising income inequality suggests that the economic trajectories of children on these two tracks may be diverging, despite widespread declines in child poverty during the late 1990 s. Our primary goal is to document racial differentials in child poverty, while evaluating the potentially divergent economic paths among America's racial and ethnic minority children, many of whom are immigrants. The key question here is not whether racial minority children and immigrants are able to escape poverty but whether they are joining the American economic mainstream.

\section{DATA AND MEASURES}

Our analyses are based on 1990 and 2000 data from the Integrated Public Use Microdata Samples (IPUMS) drawn from the decennial censuses (Ruggles et al., 2003). Data were weighted to correct for underrepresented segments of the population, ensuring a nationally representative sample that includes minorities and immigrants.

Our sample is limited to children aged 17 and younger who are related to the head of household, or whose parent is an unmarried partner of the household head (or householder). 
Children who head households or who are married to household heads are excluded from our analysis. Each child is linked to family and parental information, including information on their parents' marital or cohabiting partners. A small number of cases lacking basic demographic information for the head of household are excluded from the sample. The total sample includes 3,208,706 children in 1990 and $3,577,175$ in 2000 .

We also draw secondary samples for the purpose of comparing the income distributions of families with and without children. Individuals aged 12 to 59 not residing in group quarters are weighted with the person weight and aggregated to the level of the household and then the family. This sample includes 3,935,446 families in 1990 and $4,727,901$ families in 2000. Children were present in $51 \%$ of families in 1990 and $46 \%$ of families in 2000 .

\section{Measures}

Poverty and Inequality. Children are defined as poor when they live in families with incomes below the official poverty income thresholds for families with their specific size and configuration (i.e., adults and children), as determined by the Office of Management and Budget. Family income is measured in the year before the year of enumeration. This means that poverty status for 1990 and 2000 is based on money income and poverty thresholds for 1989 and 1999, respectively.

Officially, poverty is based on income of the family, but children may be living in households in which family members and nonfamily members pool incomes (Bauman, 1999; Carlson \& Danziger, 1999). This is sometimes the case for children living with a cohabiting parent and partner. Nearly one in seven children living with a single mother actually resides with a cohabiting couple, and $43 \%$ of cohabiting couples live with children (Lichter \& Qian, 2004). In our analysis, we redefine unmarried partners and their co-resident children as a social family (see Manning \& Brown, 2006, for similar approach). We supplement official child poverty statistics with measures of child poverty adjusted for these living arrangements. For each cohabiting couple, we combine the household head's family income with that of the unmarried partner, and then compare this income to the appropriately adjusted poverty threshold (i.e., family size is adjusted upward to include the cohabiting partner and any additional children residing with them).

Race, Nativity Status, and Family Structure. Race and ethnicity data were used to identify five distinct subgroups of children: nonHispanic white, non-Hispanic black, Native American, Asian and Pacific Islander, and Hispanic. With the exception of Native Americans, immigrant children were defined as those who are immigrants themselves (i.e., first-generation immigrants) or are the children of one or two immigrant parents (i.e., second-generation immigrants). Native children who were born in the United States to two native-born parents (i.e., third-generation) or who were born abroad to native-born Americans were identified as natives (for similar approach, see Hernandez, 2004; Van Hook et al., 2004).

For the first time, individuals in the 2000 census were able to claim more than one race. We used variables detailing Hispanic origins and race combinations to classify those claiming mixed race origins. Any person claiming Hispanic origin was classified as Hispanic; and any person claiming black, but not Hispanic, origin was designated as nonHispanic black. Those claiming mixed white race, but not black or Hispanic background, were classified as non-Hispanic white. Asianorigin and Native American individuals with no specific black, Hispanic, or white claims were labeled Asian and Native American respectively. Depending on the analyses, we 
also classify children as living in (a) marriedcouple families, (b) various types of femaleheaded families, and (c) cohabiting-couple families (i.e., their unmarried parents are cohabiting). Children in female-headed families are further distinguished on the basis of their mothers' employment patterns during the previous year. Women who usually worked 35 or more hours per week were considered full-time workers; women who had jobs but worked fewer than 35 hours were labeled part-time. We also identified children whose mothers were unemployed or not in the labor force.

\section{Analytic Strategy}

The first segment of our analysis focuses on racial differentials and changes in child poverty during the 1990s, and uncovers the extent to which they reflect new patterns of maternal employment and family structure. We use methods of direct standardization, as described in the Categorical Data Analysis System (CDAS), Version 3.5 (Eliason, 2002). Child poverty rates are calculated as the number of poor children divided by the total number of children, multiplied by 100 . Overall poverty rates are the weighted sums of group-specific poverty rates. The overall poverty rate, for example, is equal to race-specific poverty rates, weighted by race groups' representation in the overall population and then summed. Thus, we can determine what the overall poverty rate would be given a differently distributed population. We can calculate, for example, what the 2000 poverty rate would have been if family structure remained unchanged since 1990 by applying 1990 population compositional "weights" to 2000 group-specific poverty rates.

By computing hypothetical poverty rates absent changes in composition, and comparing them to observed changes, we can demonstrate the degree to which compositional shifts (in family structure and maternal work) affect poverty trends. Subtracting the difference between the crude and compositionstandardized rates from the difference in the crude rates, then dividing the result by the difference in the crude rates, yields the proportion of the crude rate change attributable to shifts in population composition. We can determine, for example, the degree to which declines in poverty between 1990 and 2000 may be attributed to shifts in family structure.

The second element of our analysis involves evaluating income growth and the changing distribution of poverty and affluence across racial groups and various subpopulations of America's children and families. Measures of income growth and inequality are based on income-to-needs ratios and their distribution across subgroups of children. Income-to-needs ratios are calculated by dividing children's family income by their family-specific poverty income threshold. An income-to-poverty ratio of 2.5 indicates that the child lives in a family with an income 2.5 times its poverty threshold. ${ }^{6}$ Change in children's income inequality between 1990 and 2000 is measured with the ratio of the 80th to 20th percentiles in their income-toneeds distribution. ${ }^{7}$ This provides a measure of the gap between rich and poor children. The ratio of the 50th to 20th percentiles shows the income gap between poor children and average children (i.e., children in families with incomes at the median). These analyses allow us to track changes in inequality within and between groups.

\section{RESULTS}

\section{Changes in Child Poverty, 1990 to 2000}

Data in Table 8.1 highlight recent changes in child poverty rates for whites, African Americans, Native Americans, Asian Americans, and Hispanics. In the 1990s, 
child poverty rates declined from 17.8 to $16.1 \%$. These declines were not uniform across racial groups. ${ }^{8}$ Declines were modest for non-Hispanic whites compared with those of racial minority children. African American children experienced declines in poverty from $39 \%$ in 1990 to $32 \%$ in 2000 , and Native Americans had similarly large declines in poverty. Any optimism implied by substantial reductions in poverty over the past decade must be balanced by the fact that these minority children still had the highest poverty rates in 2000. Asian Americans, on the other hand, had the lowest poverty rate of all racial minorities in 2000.

Our results also indicate that children of immigrant families generally had higher poverty rates than their native counterparts did. Black children are the only group in which the poverty rate was substantially higher for natives than for immigrants. Nativity differences were less dramatic among Hispanics-undoubtedly reflecting the disadvantaged socioeconomic status of the native-born rather than upward mobility of Hispanic immigrants. Moreover, with the exception of Asians, trends in child poverty during the 1990s were more advantageous for natives than for immigrants. Among blacks and Hispanics, poverty rates declined faster for natives than for immigrants, and among whites, immigrant poverty rates rose whereas those of natives declined. For Asian and Pacific Islanders, the child poverty rate for immigrant children declined, while it increased among the native born from $9.7 \%$ in 1990 to $10.3 \%$ in 2000 .

Family Structure and Changes in Child Poverty. Child poverty is strongly associated with family structure. Children in marriedcouple families are much less likely to live in poverty than are children in female-headed families. This raises an obvious question: Did declines in poverty reflect salutary changes in family structure over the 1990s?
Table 8.1 provides official and standardized child poverty rates for 2000 . Standardized rates assume that children were distributed across family types in 2000 as they were in 1990. In other words, we imagine what poverty rates might look like had family structure not changed during the 1990s (i.e., the same shares of children lived with married couples, cohabiting couples, single male-headed families, single evermarried female-headed families, and nevermarried female-headed families). The results indicate that child poverty would have declined from $17.8 \%$ in 1990 (column 1) to about $15 \%$ in 2000 (column 3) in the absence of changes in children's living arrangements. The observed decline in child poverty during the 1990 s was smaller. Similar patterns are observed for all racial groups except for Asian immigrants when we standardize by 1990 race-specific family patterns. Thus, for the decade of the 1990s, changes in family structure slowed the downward trend in child poverty rates (cf. Lichter \& Crowley, 2004).

Column 4 presents standardized poverty rates for 2000 using family structure of the total population of children. In other words, how would child poverty rates differ if all children were uniformly distributed across married-couple and single-parent families? The results indicate that poverty rates would be higher among whites and Asian Americans, but lower among African Americans and Native Americans. This means that whites and Asian Americans are much more likely to live in low risk married-couple families, whereas African and Native Americans tend to live in single-parent families, which typically have high poverty rates. Child poverty rates for Hispanics change little with standardization because the family structure of Hispanic children is close to the national average for all children. Notably, Hispanic children of immigrant families are more likely than are thirdgeneration Hispanic children (i.e., those with 
Table 8.1 Child Poverty by Race, and Poverty Standardized by Family Structure, 1990 and $2000^{1}$

\begin{tabular}{|c|c|c|c|c|}
\hline & 1990 & 2000 & $\begin{array}{c}1990 \\
\text { Standard }\end{array}$ & $\begin{array}{c}2000 \\
\text { All Races } \\
\text { Standard }{ }^{3}\end{array}$ \\
\hline All Races & 17.82 & 16.07 & 15.02 & 16.07 \\
\hline $\begin{array}{l}\text { White Non-H } \\
\text { All } \\
\text { Native } \\
\text { Immigrant }\end{array}$ & $\begin{array}{c}10.82 \\
10.88 \\
9.76\end{array}$ & $\begin{array}{r}9.10 \\
8.98 \\
10.76\end{array}$ & $\begin{array}{r}8.42 \\
8.25 \\
10.49\end{array}$ & $\begin{array}{l}11.30 \\
11.07 \\
14.03\end{array}$ \\
\hline $\begin{array}{l}\text { Black Non-Hi } \\
\text { All } \\
\text { Native } \\
\text { Immigrant }\end{array}$ & $\begin{array}{l}39.24 \\
40.53 \\
19.47\end{array}$ & $\begin{array}{l}31.86 \\
33.24 \\
19.07\end{array}$ & $\begin{array}{l}30.72 \\
31.68 \\
18.62\end{array}$ & $\begin{array}{l}21.30 \\
21.62 \\
17.76\end{array}$ \\
\hline $\begin{array}{l}\text { Native Americ } \\
\quad \text { All }\end{array}$ & 38.05 & 30.45 & 29.19 & 26.77 \\
\hline $\begin{array}{l}\text { Asian and Pac } \\
\text { All } \\
\text { Native } \\
\text { Immigrant }\end{array}$ & $\begin{array}{r}15.83 \\
9.72 \\
17.15\end{array}$ & $\begin{array}{l}14.34 \\
10.28 \\
14.92\end{array}$ & $\begin{array}{r}14.05 \\
9.15 \\
14.63\end{array}$ & $\begin{array}{l}17.22 \\
10.88 \\
18.30\end{array}$ \\
\hline $\begin{array}{l}\text { Hispanic } \\
\text { All } \\
\text { Native } \\
\text { Immigrant }\end{array}$ & $\begin{array}{l}31.35 \\
31.03 \\
31.65\end{array}$ & $\begin{array}{l}27.11 \\
25.09 \\
28.42\end{array}$ & $\begin{array}{l}27.01 \\
23.71 \\
28.30\end{array}$ & $\begin{array}{l}26.72 \\
20.56 \\
30.08\end{array}$ \\
\hline
\end{tabular}

SOURCE: U.S. Census Bureau, IPUMS 5\% sample.

${ }^{1}$ Family structure categories: married couple, cohabiting couple, single male head, single ever-married female head, single never-married female head.

${ }^{2} 2000$ poverty rates standardized by within-group 1990 family structure.

${ }^{3} 2000$ poverty rates standardized by all children's 2000 family structure.

native-born parents) to live with two parents, which places downward pressure on poverty rates. The important point, however, is that racial differences in family structure account for some, but not all of the differences in child poverty. For example, if black children lived in married-couple families in the same proportions as whites, their poverty rates would still be nearly double those of white children.

More than ever before, evaluating poverty among children living in singleparent families is made difficult by rising shares of children who also live with a parent's cohabiting partner (Lichter \& Crowley, 2004; Manning \& Lichter, 1996).
Indeed, as shown in Table 8.2, our estimates suggest that the share of children living in cohabiting-couple families increased from 3.46 to $5.43 \%$ of all children between 1990 and 2000. Increases were apparent for all racial minorities, and for both natives and immigrants, during the 1990s. However, children in immigrant families are less likely than are children with native-born parents (regardless of race) to live in cohabitingcouple families. In 2000, the shares of nonHispanic black natives, Native Americans, and native-born Hispanics in these types of families were well above the national percentage. 


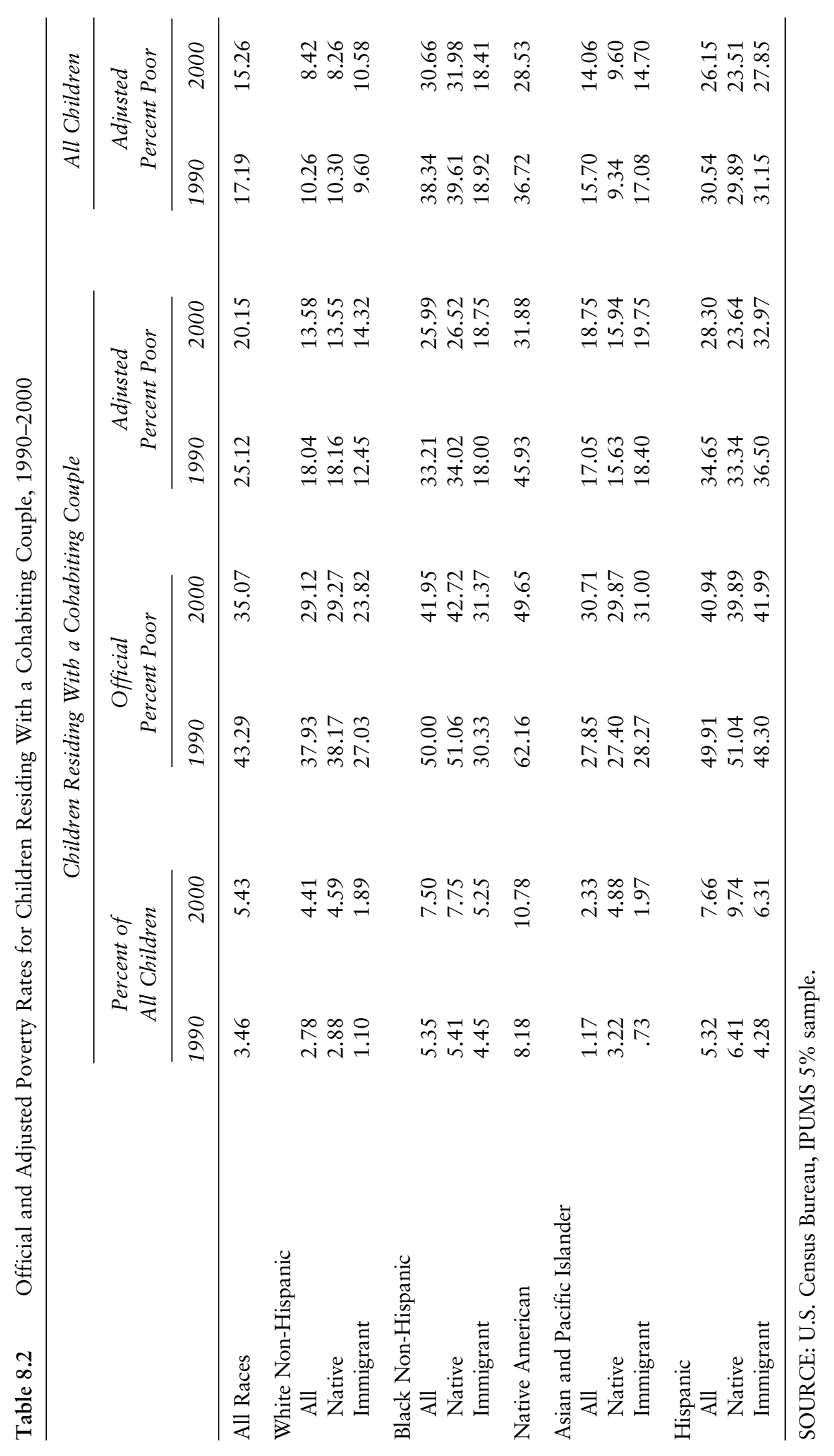


Table 8.2 also includes the official poverty rate for children living with cohabiting parents, and an adjusted rate (columns 5-6), based on the combined incomes of each partner compared with an adjusted poverty threshold (because of adding an additional family member and any additional children residing with them). We assume, perhaps unrealistically, that partners pool their incomes to the benefit of co-residential children. By comparing the official and adjusted poverty rates, we can derive an upper-bound estimate of reductions in measured poverty if children's cohabiting partners married. Among all children residing in cohabiting-couple households, the 2000 child poverty rate would drop from $35 \%$ to $20 \% .^{9}$ Reductions are evident among all groups. At a minimum, our results suggest that the official poverty rate is overestimated as a familybased measure, and has not kept pace with children's changing living arrangements, especially the rise in the percentage of children living with cohabiting couples.

The final two columns in Table 8.2 present overall 1990 and 2000 child poverty rates when adjusted poverty substitutes for official poverty among children living in cohabiting-couple families. By comparing these adjusted rates to the overall official rates presented in Table 8.1, we observe the effects of cohabitation on national estimates of child poverty. In 2000, the adjusted poverty rate was $15.26 \%$, compared with an observed rate $16.07 \%$ (Table 8.1 ). The differences were also small for each race and nativity group. The measurement effects of cohabitation on overall child poverty rates are minimal. But they became larger during the 1990s with the rise in children living in such families.

Maternal Employment and Poverty Among Children in Female-Headed Families. Children living in female-headed families have much higher poverty rates than do children living in married-couple families (Lichter \& Crowley, 2004). Still, even among this disadvantaged population subgroup, racial differences in child poverty remain large. As shown in Table 8.3, poverty rates among children living in female-headed single families ranged from a high of more than one-half of immigrant Hispanic children $(52 \%)$ to a low of less than $28 \%$ among white children with immigrant parents in 2000. The good news is that poverty rates for all such "at risk" children declined by nearly 10 percentage points (from 49 to $40 \%$ ) during the 1990s, and economic gains are evident among all race and nativity groups. Yet, with the exception of Asians, poverty rates of children residing with native-born single mothers declined much more rapidly than among children with immigrant single mothers. For example, poverty among white children with native single mothers declined from $37 \%$ in 1990 to $29 \%$ in 2000 , but declined far less-from $30 \%$ to $28 \%$ among those with immigrant single mothers. Although these recent declines are encouraging, poverty rates among children living in female-headed families remain high by almost any standard.

Recent declines in poverty among children living in female-headed families imply that family changes alone cannot explain recent declines in child poverty. Previous studies indicate that changing maternal employment may have played a large role in the changing economic fortunes of such children (Lichter, Qian, \& Crowley, 2005; Manning \& Brown, 2006). Column 3 of Table 8.3 shows the standardized child poverty rate in 2000 using the 1990 race-specific employment rates of single mothers as the standard. Poverty among children living with single mothers would have declined to $43 \%$ rather than $40 \%$ if there were no change in maternal employment patterns during the 1990s. In other words, the rise in maternal 
Table 8.3 Child Poverty by Race, and Poverty Standardized by Women's Employment Among Children Residing With Single Mothers, 1990 and 2000'

\begin{tabular}{|c|c|c|c|c|}
\hline & 1990 & 2000 & $\begin{array}{c}1990 \\
\text { Standard }^{2}\end{array}$ & $\begin{array}{c}2000 \\
\text { All Races } \\
\text { Standard }^{3}\end{array}$ \\
\hline All Races & 49.06 & 39.83 & 42.93 & 39.83 \\
\hline $\begin{array}{l}\text { White Non-H } \\
\quad \text { All } \\
\text { Native } \\
\text { Immigrant }\end{array}$ & $\begin{array}{l}37.13 \\
37.35 \\
29.73\end{array}$ & $\begin{array}{l}29.10 \\
29.15 \\
27.92\end{array}$ & $\begin{array}{l}31.66 \\
31.82 \\
27.97\end{array}$ & $\begin{array}{l}32.44 \\
32.63 \\
28.10\end{array}$ \\
\hline $\begin{array}{l}\text { Black Non-Hi } \\
\text { All } \\
\text { Native } \\
\text { Immigrant }\end{array}$ & $\begin{array}{l}59.92 \\
60.63 \\
37.32\end{array}$ & $\begin{array}{l}47.78 \\
48.46 \\
34.90\end{array}$ & $\begin{array}{l}51.62 \\
52.34 \\
34.95\end{array}$ & $\begin{array}{l}45.85 \\
46.35 \\
36.61\end{array}$ \\
\hline $\begin{array}{l}\text { Native Americ } \\
\quad \text { All }\end{array}$ & 61.24 & 49.38 & 53.02 & 46.42 \\
\hline $\begin{array}{l}\text { Asian and Pac } \\
\text { All } \\
\text { Native } \\
\text { Immigrant }\end{array}$ & $\begin{array}{l}40.76 \\
34.43 \\
43.60\end{array}$ & $\begin{array}{l}33.12 \\
28.34 \\
34.71\end{array}$ & $\begin{array}{l}35.39 \\
30.91 \\
37.11\end{array}$ & $\begin{array}{l}32.13 \\
30.04 \\
32.84\end{array}$ \\
\hline $\begin{array}{l}\text { Hispanic } \\
\text { All } \\
\text { Native } \\
\text { Immigrant }\end{array}$ & $\begin{array}{l}59.37 \\
60.22 \\
57.62\end{array}$ & $\begin{array}{l}49.30 \\
47.55 \\
52.00\end{array}$ & $\begin{array}{l}52.68 \\
53.52 \\
51.89\end{array}$ & $\begin{array}{l}45.89 \\
44.83 \\
48.02\end{array}$ \\
\hline
\end{tabular}

SOURCE: U.S. Census Bureau, IPUMS 5\% sample.

${ }^{1}$ Women's employment categories: full-time (35+ hours per week), part-time (fewer than 35 hours per week), unemployed, not in the labor force.

22000 poverty rates standardized by 1990 women's employment patterns in this race group and family type.

${ }^{3} 2000$ poverty rates standardized by 2000 women's employment patterns among all races in this family type.

employment accounted for about one-third of the observed 9-percentage-point decline in poverty for children in single-mother families ([42.93-39.83] × $100 /$ [49.06-39.83]). Increases in maternal employment in the 1990 s seem to have lifted many "at risk" children out of poverty.

Recent employment patterns among single mothers, however, had different effects on children of different racial and ethnic groups (Table 8.3). Among white children with native-born parents, the rise in maternal employment accounted for $33 \%$ of the 8-percentage-point decline in child poverty during the 1990s. For black and Native American children living in native-born single-mother families, the rise in employment accounted for about 31 to $32 \%$ of the roughly 12-percentage-point declines in child poverty. Rising maternal employment accounted for $47 \%$ of the decline among native-born Hispanics.

Among children residing with single immigrant mothers, however, maternal employment patterns can explain little of the recent changes in poverty. For example, changing 
maternal work patterns explain almost none of the 2- to 3-percentage-point poverty decline among children of white and black immigrant families. And, for children in immigrant Hispanic families, declines in child poverty during the 1990s would have been greater if 1990 maternal employment patterns had continued in 2000. Although welfare reform appears to have improved some children's economic circumstances by pressuring more single mothers to enter the labor force, this has not been the case for immigrant children.

Do differences in maternal employment account for racial and ethnic differences in female-headed families' rates of child poverty? To answer this question, we calculate employment-standardized child poverty for 2000. These figures assume that maternal employment patterns among single mothers in each racial group are identical to those of all single mothers. Our results indicate that racial differences in child poverty (column 2) are not simply the result of racial differences in the work habits of children's mothers. Blacks, Native Americans, and Hispanicsregardless of nativity status-would have much higher rates of child poverty than would non-Hispanic white or Asian children, even if maternal employment rates were the same for each racial group. Other explanations must be considered (e.g., differences in wage rates caused by low education, limited opportunities, or discrimination).

To sum up, recent declines in poverty rates among children living in single-parent families have been welcome news. Still, racial differences in child poverty remain large, with nearly half of all such African American, Hispanic, and Native American children living in poverty in 2000. Two countervailing factors have shaped recent trends in poverty-family instability and maternal employment. Differentials in child poverty rates were given impetus by the racial differences in female-headed families with children. On the other hand, maternal employment among single mothers increased rapidly in the 1990s, which provided an important hedge against child poverty for most groups considered here. However, employment differences alone cannot explain differences in poverty rates across racial or immigrant groups of children.

\section{Changes in Income Inequality Among America's Children}

The 1990s brought declines in child poverty rates for most racial, ethnic, and immigrant groups. But a narrow focus on declining poverty rates may cause us to overlook evidence that poor children may be poorer today than in the past, or that the incomes of poor children may have increased in absolute terms but declined relative to rising incomes of middle-class and affluent children. In other words, did income inequality among children increase (or decrease) during the 1990s as the income gap between poor and rich children widened (or narrowed)? Has growing racial diversity reinforced income inequality during the past decade? And has the racial distribution of affluent children become "whiter" whereas the poor increasingly comprise children of racial minority and immigrant families?

Income-to-Poverty Ratios. We begin with simple comparisons of trends in children's family incomes over the 1990s. Table 8.4 presents income-to-needs ratios for the overall population and for each racial and nativity group. Overall, the family incomes of poor children (i.e., children at the 20th percentile) increased from $10 \%$ over $(1.10$ times) the poverty threshold in 1990 to $19 \%$ over (1.19 times) the threshold in 2000 . Income-to-needs ratios increased from 2.50 to 2.61 among children at the median of family income (i.e., the "middle class"), and from 4.31 to 4.74 among children at the top of the income distribution. 
Evidence of whether income inequality increased in the 1990s is reflected in the ratio of the family income at the 80th percentile to the family income at the 20th percentile (last two columns, Table 8.4; see Danziger \& Gottschalk, 2004, for similar approach). A higher ratio indicates greater income inequality. The ratio of income of affluent to poor children increased only slightly in the 1990s, from 3.92 to 3.98. In other words, affluent children have roughly 4 times as much family income as poor children. Based on this measure, there is little indication of large increases in income inequality among children in the 1990s. ${ }^{10}$

Our examination of racial and nativity differences in income and income inequality suggests at least three main conclusions. First, and perhaps most significant, the average family incomes of children at the bottom of the income distribution increased during the 1990s for each of the racial and immigrant groups considered here. Quite simply, the poor did not become absolutely poorer during the 1990s; indeed, their incomes grew. At the same time, income growth was also apparent at the 50th and 80th percentile for these groups of children, which raises questions concerning differentials in income growth across the income distribution (an issue to which we will return).

Second, racial and nativity differences in family income remain very large at each location in the income distribution. For example, for non-Hispanic white children at the 20th income percentile, their family income was $66 \%$ higher than the poverty income threshold. Among their non-Hispanic black counterparts, incomes were $39 \%$ lower than the poverty threshold. Clearly, America's poorest African American children are much poorer than America's poorest white children. Poor children of immigrant families (for each racial group except blacks) are poorer than poor children with native-born parents. At the other end of the income distribution, affluent white and Asian children, not surprisingly, had much higher incomes than the most affluent black, Native American, or Hispanic natives or immigrants (column 6, Table 8.4).

Third, for historically disadvantaged children, such as blacks, Native Americans, and Hispanics, income inequality decreased in the 1990s (except for black immigrants). This is indicated by the increasing ratio of the racespecific median incomes to the overall U.S. median income (columns 7-8). This also is indicated by the declining ratios of incomes at the 80th to the 20th percentiles. For example, among non-Hispanic blacks, the group with the highest income inequality, the incomes of affluent children were 6.6 times higher than the incomes of poor children (at the 20th percentile) in 1990. However, this figure declined to 5.4 by 2000 . The decline reflects faster income growth (on a percentage basis) at the bottom than at the top of the income distribution for racial minority children. For these minority children, declines in child poverty during the 1990s were accompanied by the growth of income among poor children and declines in income inequality. This appears to be a significant departure from the results of past studies based on pre-1990 data (e.g., Lichter \& Eggebeen, 1993).

Distribution of Poverty and Affluence. We have described income growth among poor, middle-class, and affluent children and changing inequality among racial and immigrant groups. But any interpretation of income growth must also consider the changing percentages of children in particular income classes. Indeed, it may be the case that more poor children are deeply impoverished today, or that poor children who escape poverty remain in families with modest incomes (i.e., the "near poor"). Any optimism implied by increases in income among poor children must be tempered if the percentage of poor and near poor increased during the past decade. A similarly less 


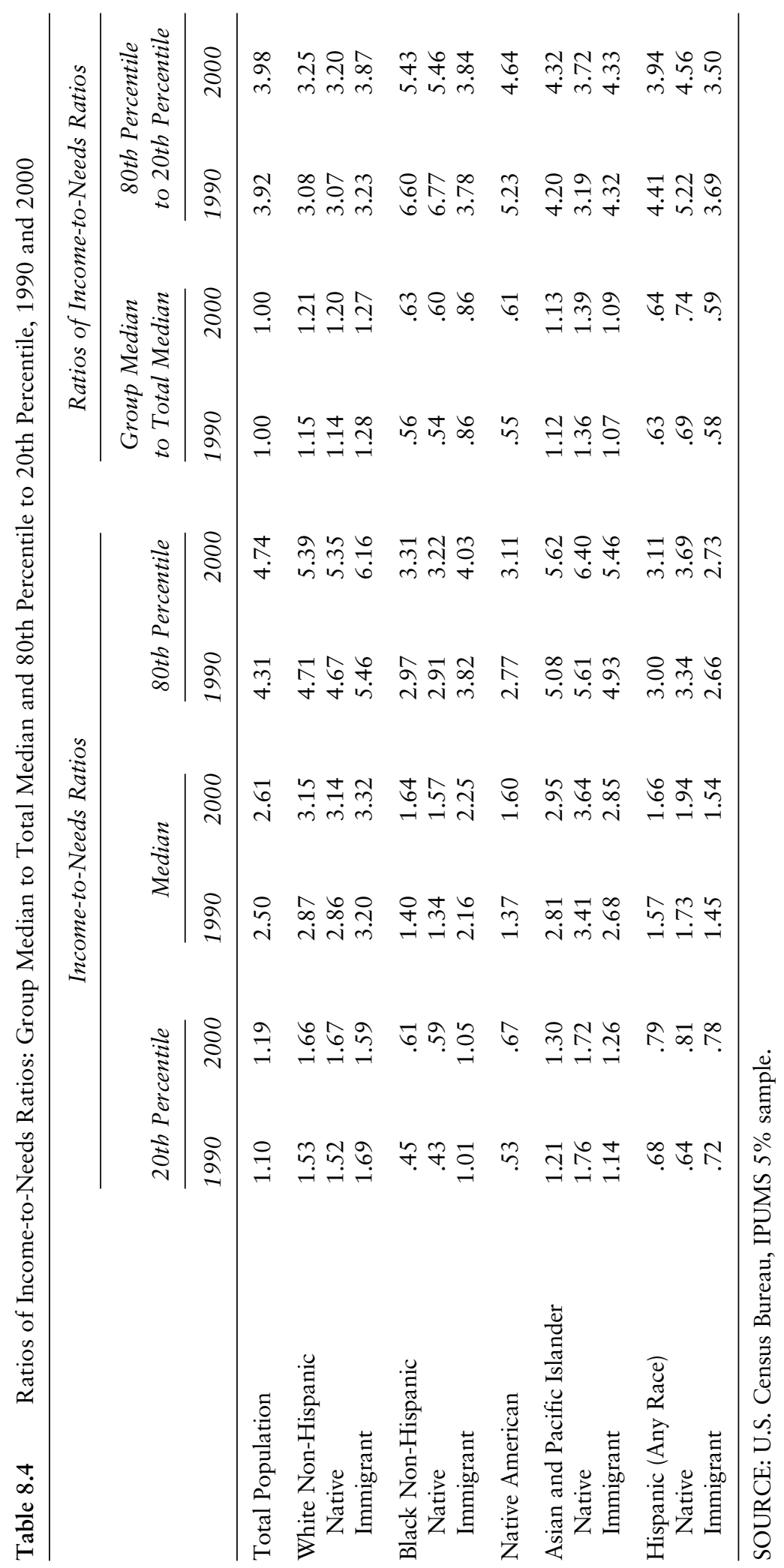


sanguine interpretation is required of income gains among the middle class or affluent if the percentage of middle-class or affluent children declined during the 1990s.

In this section, we calculate the percentage of children in deep poverty, which includes children in families with incomes less than one-half their poverty income threshold. Marginal poverty includes children with family incomes that are at least one-half, but less than $100 \%$ of their poverty threshold. Children in nonpoor families with incomes less than double their poverty threshold are included in the near poverty category. Children with family incomes at least four times their poverty threshold are considered affluent for our purposes. Middle-class children fall between the near poor and affluent, with family incomes that are at least double, but less than four times their family's poverty income threshold.

Overall, the percentage of children living in deep poverty declined from $8.3 \%$ in 1990 to $6.9 \%$ in 2000 (Figure 8.1 ). However, the percentage in marginal poverty or near poverty remained largely unchanged in the 1990s. The implication is significant: Overall declines in child poverty during the 1990s apparently reflected mostly the declining percentage of the most impoverished children. At the same time, the middle-class share declined slightly, chiefly because of increases in the share of affluent children.

Racial and nativity comparisons reveal some interesting facts. First, the percentage of children living in deep poverty generally declined in the 1990s, especially among African American children. Second, the percentage of children in near poverty increased for all groups except for native-born white, immigrant black, and immigrant Asian children. One implication is that increases may reflect declines in poverty as the poor have moved to the near-poor category. Third, among the most disadvantaged groups, including blacks, Native Americans, and Hispanics, the poor and near poor outnumber the middle class and affluent. In 2000, $65 \%$ of Hispanic immigrants, and $60 \%$ of black natives and Native Americans, were poor or near poor, and 35 and 40 percent, respectively, were middle class or affluent. Fourth, the percentage of children living in affluence increased among every race/ethnic and nativity category. Not only did the income of the affluent increase, but also the share of affluent children increased. Fifth, among Hispanics and Asians, children in immigrant families had lower rates of affluence, but black and white immigrants had higher rates of affluence than their native counterparts. Among Hispanic immigrants, for example, only $8 \%$ were affluent in 2000the smallest share of any race and nativity combination. Native-born Asians, on the other hand, had the highest rates of affluence- $-45 \%$ in 2000. These racial and immigrant differences in poverty and affluence clearly reveal inequality among American children.

Not surprisingly, these large racial and nativity differences in economic well-being reveal themselves in striking differences in the racial composition of the deeply poor, marginally poor, near-poor, middle-class, and affluent child populations. Figure 8.2 reveals that in 2000 the majority (more than two-thirds) of deeply poor children were racial minorities. Moreover, the small decline during the 1990s in the percentage of deeply poor children who were white or black was offset by increases in the percentage of Hispanic. By contrast, only $20 \%$ of affluent children in 2000 were racial minoritieswith roughly equal shares of Asians, Hispanics, and blacks.

Figure 8.3 presents the changes in the percentage of children in female-headed families across the five income classes. The most striking finding is that most children in female-headed families-nearly 70\%-are included in either deep poverty, marginal poverty, or near poverty. Although the share of these children in middle-class or affluent 
families increased in the 1990s, they nevertheless represent a very small proportion of such children. A similar conclusion applies to most of the groups considered here. Among native black, immigrant Hispanic, and Native American children, only a small fraction (about $20 \%$ ) is middle class or affluent.

\section{All Races}

1990

2000

White Non-Hispanic

All 1990

2000

Native 1990

2000

Immigrant 1990

2000

Black Non-Hispanic

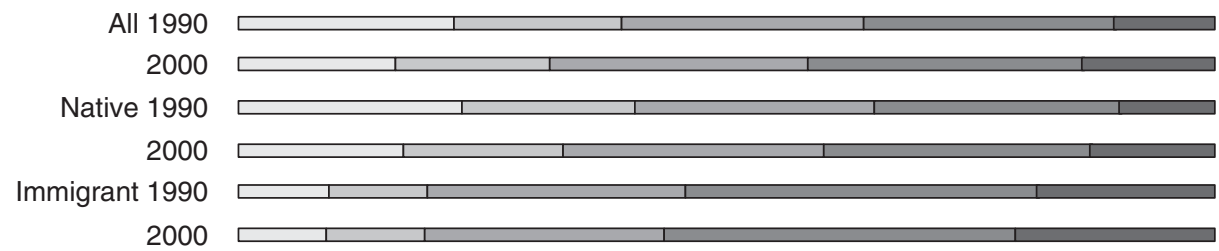

Native American

1990
2000

1990
2000
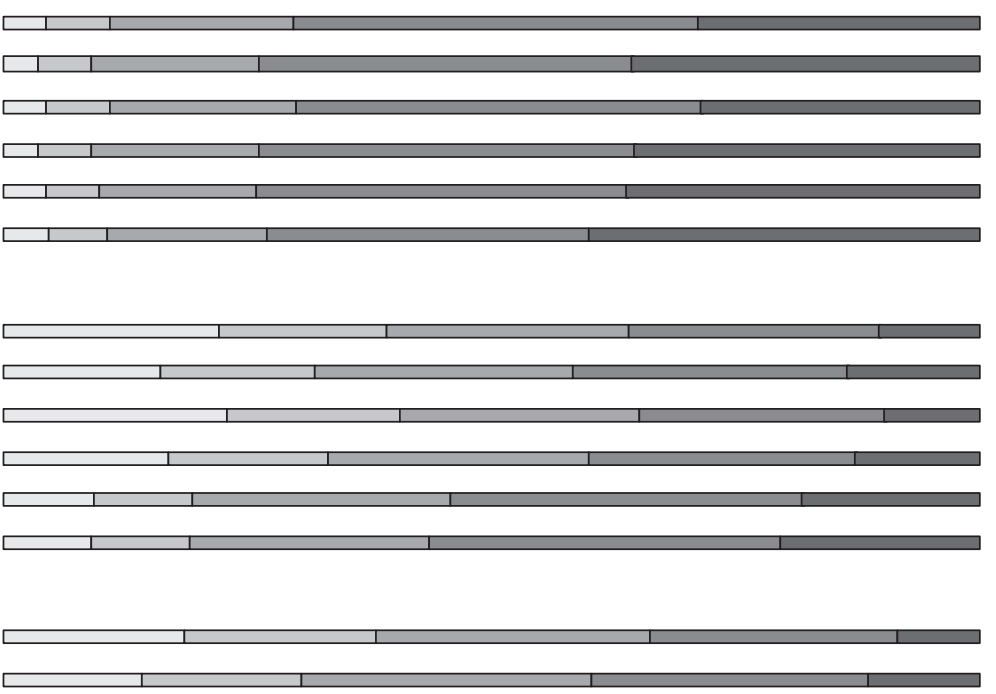

Asian and Pacific Islander

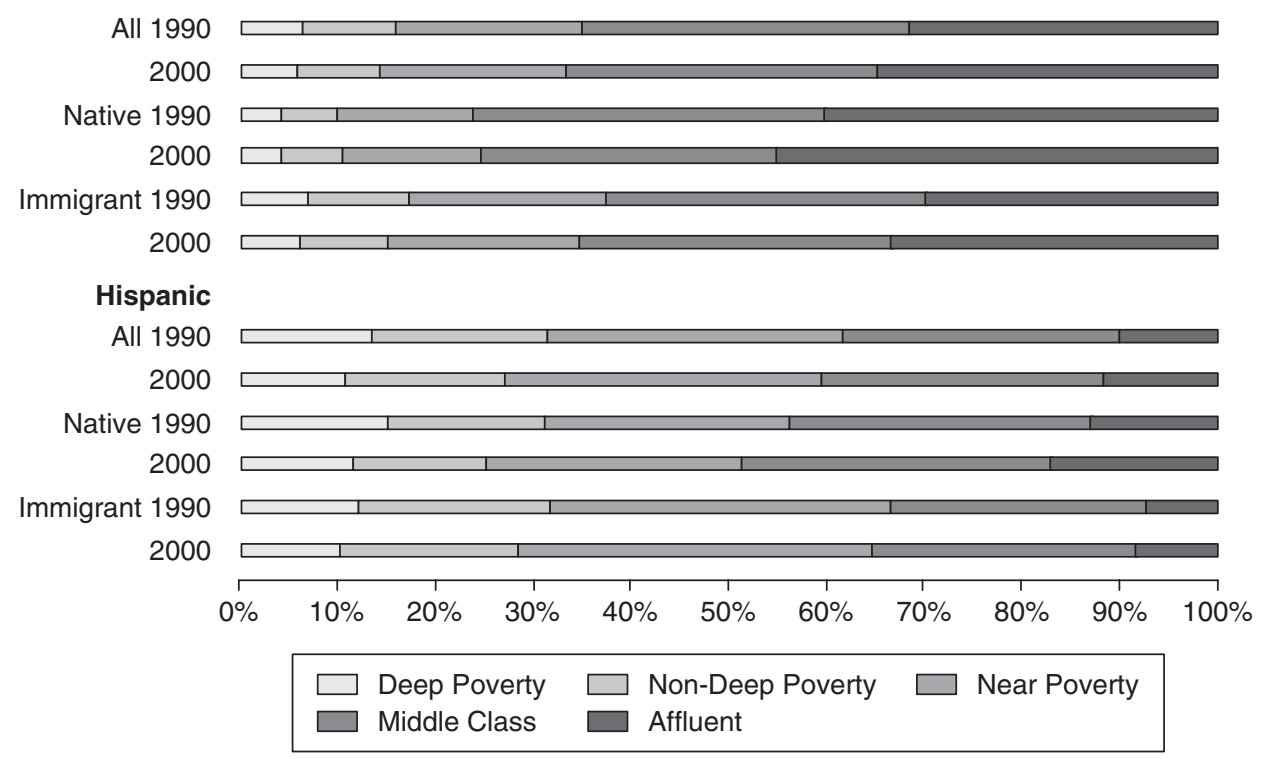

Figure 8.1 Child Poverty and Affluence by Race, All Families, 1990 and 2000

SOURCE: U.S. Census Bureau, IPUMs 5\% sample. 

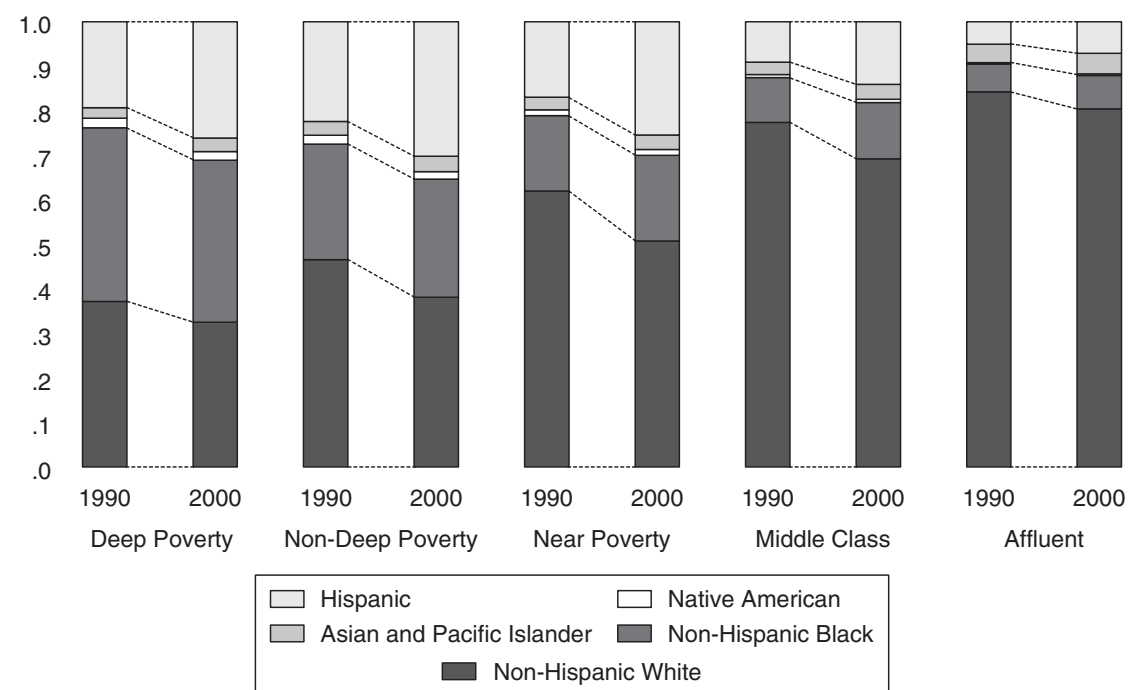

Figure 8.2

Race Distributions of Poverty and Affluence Groups, 1990 and 2000

Moreover, declines in deep and marginal poverty typically were offset by increases in the share of children who were near poor. Indeed, the near-poor category increased its population share by an amount equal to $41 \%$ of the decline in the share of poor children. The implication, of course, is that much of the decline in child poverty among female-headed families reflects shifts to near poverty rather than significant shifts to the middle class. Population shifts out of the near-poor category into the middle class likely deflate the true degree to which entry into the near-poor category offsets declines in poverty. In sum, many children in singlemother families moved out of poverty during the 1990s but few moved into the middle class. Indeed, most of these children remain economically disadvantaged but are not acknowledged as such in official government poverty statistics.

\section{Changes in Family Poverty and Affluence}

We have focused our attention on racial and immigrant differences in poverty among children with different living arrangements. But how have families with children compared with those headed by similarly aged householders without children? Has the gap in economic well-being expanded during the 1990s as the proportion of families remaining childless has grown? We address these questions with 1990 and 2000 data on poverty for families with children (Figure 8.4) and without children (Figure 8.5). ${ }^{11}$

Overall, families without children were more likely than were families with children to be at the extremes of the income distribution. For example, a higher and growing percentage of families without children lived in deep poverty $(8.1 \%$ in 1990 and $9.6 \%$ in 2000$)$. For families with children, the comparable percentages of deep poverty were roughly one-half as large and declining- $5.9 \%$ in 1990 and $5.2 \%$ in 2000 . Roughly $40 \%$ of families without children were affluent both in 1990 and 2000. The percent of affluent families with children was lower but increased from $33 \%$ to $35 \%$ during the 1990 s.

Similar patterns of inequality between families with and without children were apparent across racial groups. ${ }^{12}$ That is, a larger 


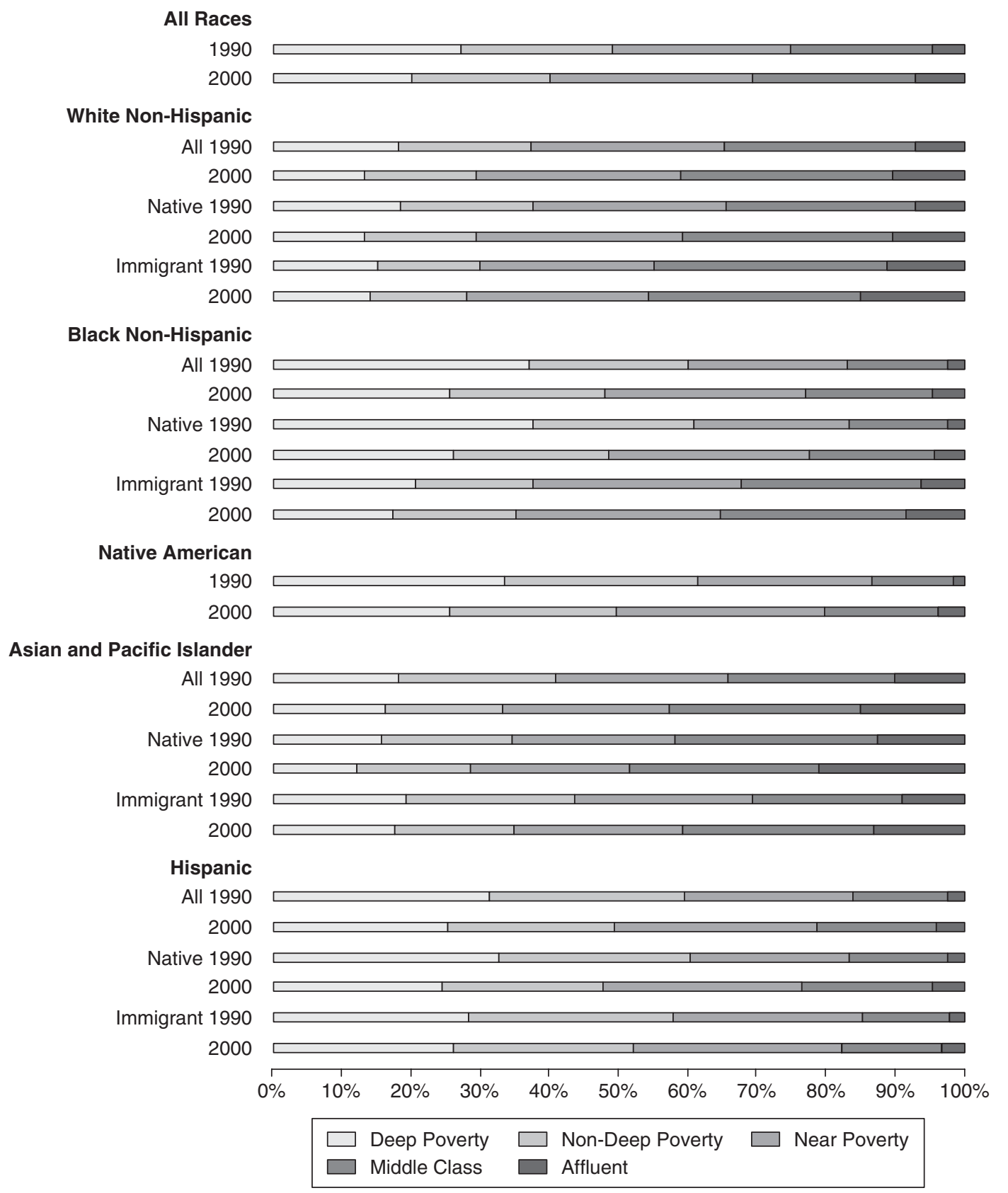

Figure 8.3 Child Poverty and Affluence by Race, All Female-Headed Families, 1990 and 2000

SOURCE: U.S. Census Bureau, IPUMs 5\% sample.

share of families without children lived in deep poverty and in affluence. The one exception is Asian American families-the percent affluent is higher among Asian families with children than among their childless counterparts. In fact, more than one-half of native Asian American families with children were affluent, a percentage exceeding even that of whites. Racial differences in poverty also tend to be smaller when families rather than children are 
All Races

1990

2000

White Non-Hispanic

All 1990

2000

Native 1990

2000

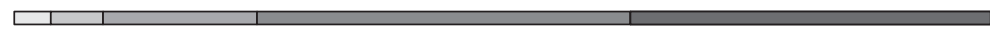

Immigrant 1990

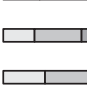

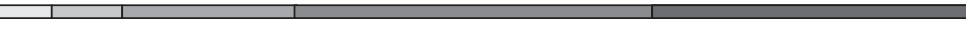

anic

Black Non-Hispanic

All 1990

2000

Native 1990

2000

Immigrant 1990

2000

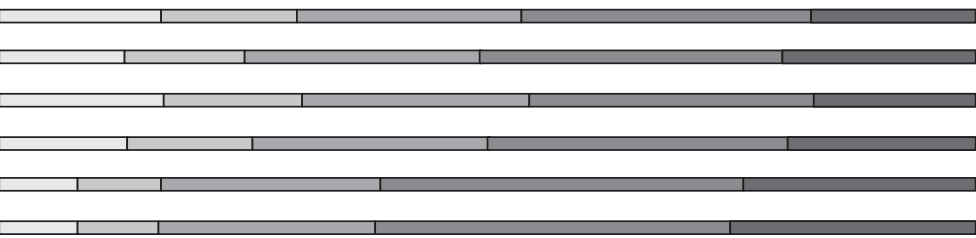

Native American

1990

2000

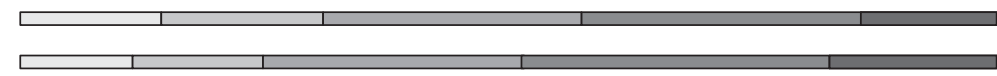

Asian and Pacific Islander

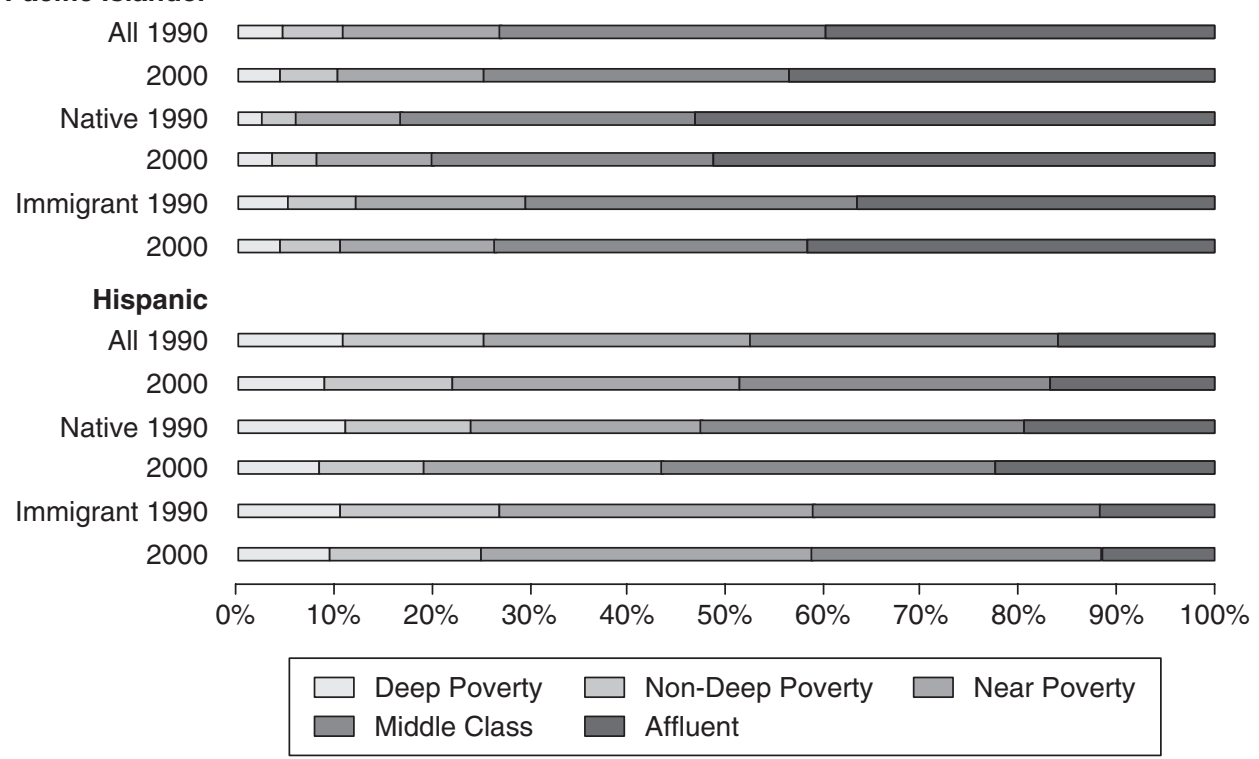

Figure 8.4 Family Poverty and Affluence by Race, Families With Children, 1990 and 2000

SOURCE: U.S. Census Bureau, IPUMs 5\% sample.

the unit of analysis (cf., Figures 8.1 and 8.4). This is attributable partly to family size and composition differences among families of different races and socioeconomic statuses.
Analyses of families give equal weight to each family whereas analyses of children weigh families by family size, which is positively associated with poverty. ${ }^{13}$ 
All Races

1990

2000

White Non-Hispanic

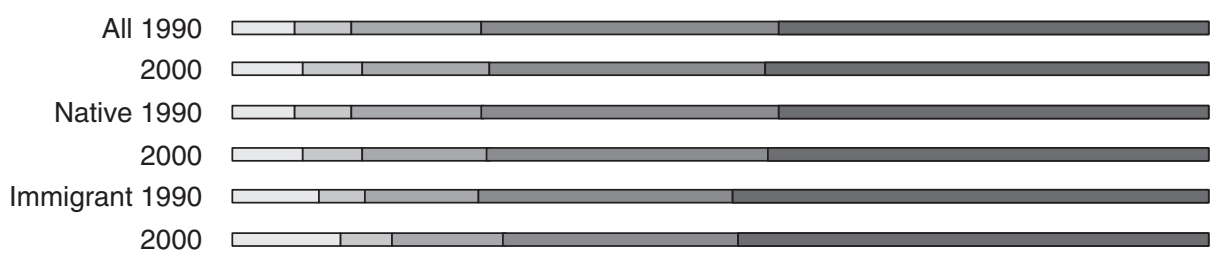

Black Non-Hispanic

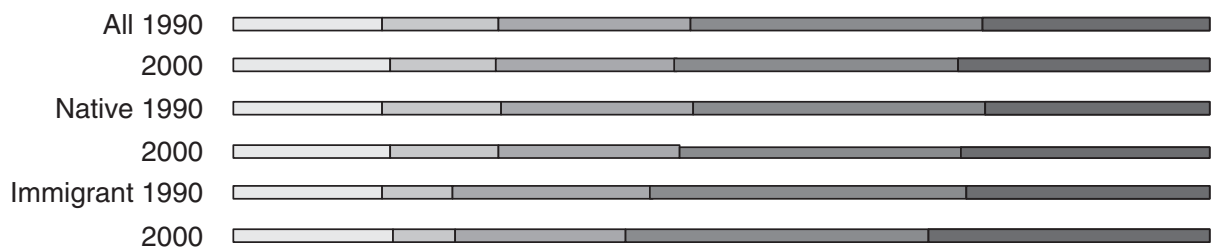

Native American

1990

2000

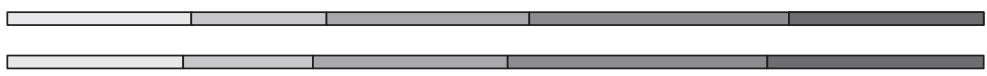

Asian and Pacific Islander

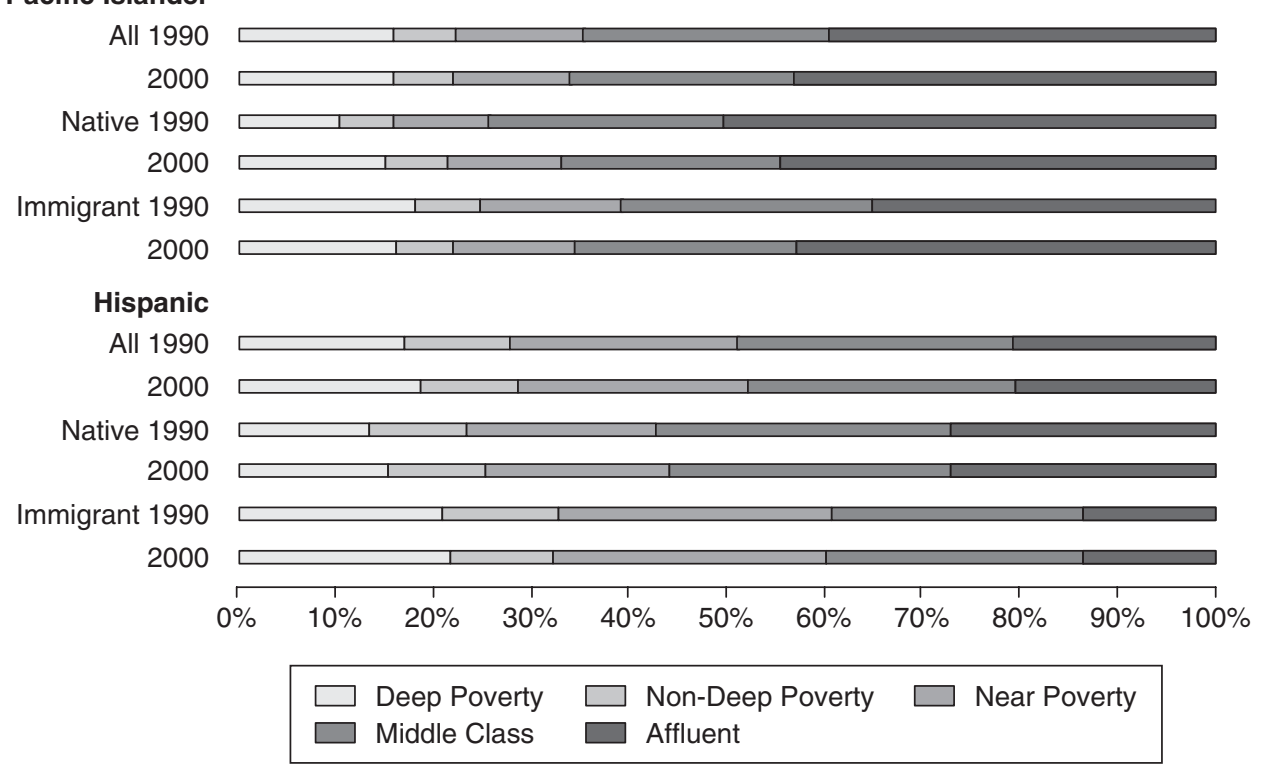

Figure 8.5 Family Poverty and Affluence by Race, Families Without Children, 1990 and 2000

SOURCE: U.S. Census Bureau, IPUMs 5\% sample.

\section{DISCUSSION AND CONCLUSION}

The 1990s ushered in a new period of growing racial and ethnic diversity in the United States. More than ever before, recent trends also have highlighted the need to better evaluate new patterns of economic incorporation of America's historically disadvantaged children of racial minority and immigrant families. As we have argued here, the current 
economic circumstances of America's minority children provide a window to the future of racial stratification and inequality. Our primary objective therefore has been to track trends in child poverty and income inequality among diverse minority groups over the 1990s. The 1990 and 2000 5\% Public Use Microdata Samples provide samples of children of sufficient size and racial diversity to achieve this objective.

At the national level, our results indicate that the 1990s were a period of widespread declines in poverty among America's children. Each of the racial and ethnic groups considered here appears to have benefited from economic and employment growth during the 1990s. Indeed, our results suggest that increasing maternal employment rather than changing family structure accounted for the largest share of the recent declines in child poverty. Unlike the pre-1990 period, when children's living arrangements shifted them away from married-couple families to high-risk single-parent families, the 1990s brought little change in children's living arrangements (Lichter \& Crowley, 2004; Iceland, 2003). Changing family structure is no longer giving demographic impetus to increasing poverty among children. Rather, the rise in maternal employment, especially among single mothers, has placed considerable downward pressure on child poverty rates nationally and across the population subgroups of minority children and children of immigrant families considered here (cf., Lichter \& Crowley, 2004). ${ }^{14}$

We began with the assumption that national trends in child poverty could mask tremendous racial and ethnic diversity in children's economic circumstances. Our results, not surprisingly, do not lend themselves to simple conclusions. On the one hand, maternal employment played a large role in accounting for declines in child poverty among minority children. On the other hand, high rates of poverty among children of minority and immigrant families cannot be explained away by existing differences in employment rates or work patterns among children's mothers. Conversely, although changes in family structure cannot fully explain trends in child poverty across population subgroups, racial differences in family structure continue to account for a significant portion of observed differences in child poverty across minority groups. Our results confirm the view that racial inequality among children cannot be discussed in isolation from the currently large group differences in out-of-wedlock childbearing, marriage, and divorce. ${ }^{15}$

At the same time, any analysis of trends and differentials in child poverty, if considered alone, may give a rather incomplete or even misleading picture of children's changing economic circumstances. Significantly, our results indicate that family incomes of America's poorest children, regardless of racial or ethnic background, increased during the 1990s at the same time poverty rates declined. Rates of deep poverty (i.e., below one-half of the poverty income threshold) also declined among children and families with children. Moreover, the growth in income inequality among children (e.g., Lichter \& Eggebeen, 1993) apparently slowed significantly during the 1990 s. These results provide a different picture than portrayed recently by McLanahan (2004), who suggested that the economic trajectories and resources of rich and poor children are now diverging. As we reported here, the familysize-adjusted incomes of the poorest children for most racial and ethnic groups increased at a similar or faster pace over the past decade than did the incomes of "average" or wealthy children (see Table 8.3). Yet, by definition, the absolute dollar gap in income between America's poor and affluent children increased during the 1990s.

Whether trends and racial differences in poverty and income during the 1990s should be viewed largely with optimism or pessimism is a matter of personal judgment or 


\section{PART II: POVERTY AMONG DIVERSE POPULATIONS AND SETTINGS}

emphasis. There can be no disagreement, however, that racial and nativity differences in economic well-being remain large in the United States. And few observers will disagree that any progress toward racial inequality has been slow, or that continuing high rates of child poverty today will reinforce existing patterns of racial inequality in the future. Only by severing the link between childhood and adult poverty (e.g., through better education, a secure safety net, or economic opportunity) will America's future take a different or faster route toward racial economic equality.

\section{NOTES}

1. Among the white population, only a small share was of Hispanic origin. Although data on Hispanic origin are not available from the 1950 census, the 1940 census indicated that 116 million of the 118 million white people were nonHispanic in origin (Gibson \& Jung, 2002). The heavy influx of Hispanics from Mexico and other Latin American countries did not begin until the 1960s.

2. The 2000 census indicates that nearly 35 million blacks lived in the United States, or roughly $12.3 \%$ of the total population (Grieco \& Cassady, 2001).

3. Previous studies have demonstrated that childhood poverty compromises development trajectories, academic achievement, and social mobility. See Duncan and Brooks-Gunn's (1997) compendium of studies on the consequences of poverty for children's development.

4. Using data from the Current Population Survey and the Survey of Income and Program Participation, Iceland, Short, Garner, and Johnson (2001) found that child poverty rates continued to surpass those of other age groups, but that the gap between child and adult poverty rates is smaller when income calculations include noncash government benefits and the Earned Income Tax Credit.

5. From 1949 to 1969 , Gottschalk and Danziger (1993) demonstrated that the large decline in poverty ( -25.7 percentage points) were entirely attributable to changes in the economy. The subsequent period, from 1973 to 1991, showed little relationship between economic change and poverty.

6. We assume that the poverty income threshold for any given child represents need. Significantly, the income-to-poverty ratio also adjusts for family size and configuration-increasing with family size to reflect increased need and economies of scale.

7. The IPUMS family income-to-needs ratio is top coded at 5.01. Calculating 80th percentiles required us to replace top-coded values with our own income-to-needs computations, based on information about family income, size, and configuration.

8. Some additional analyses revealed that the child poverty rate would have declined to $14.9 \%$ (rather than $16.1 \%$ ) during the 1990 s if the racial/ethnic composition of the child population had remained unchanged after 1990. America's changing racial composition has put upward demographic pressure on child poverty rates. At the same time, the effects of changing immigrant composition on child poverty were modest. In the absence of changes between 1990 and 2000 in the share of first-, second-, and third-generation children, the child poverty rate in 1990 would have been $15.7 \%$ (rather than $16.1 \%$ ).

9. Similar results are reported in a recent study by Manning and Brown (2006). They showed that the poverty rate was $7.6 \%$ for children living in marriedcouple families with both biological parents. For children living with cohabiting parents, the rates were 19.0 and $23.0 \%$, respectively, for children living with both 
biological parents or living with a biological parent and unrelated partner. Their analyses were based on the 1999 National Survey of American Families.

10. Conclusions about changing income inequality may be different if we compared other income percentiles, such as the 10th percentile to the 90th percentile. Blanket conclusions about changes in inequality based on these ratios are inappropriate. Income ratios and income differences among children at different locations in the income distribution may yield different interpretations. Our ratio measure in Table 8.3 indicates little change in income inequality during the 1990s. Absolute differences in income-to-poverty ratios of the poor and affluent, however, indicate large increases in inequality.

11. To be comparable, our sample of families without children includes only those in which the householder is 59 years old or younger.

12. Our secondary family samples were also classified by race. We categorized each family member's race as we did for children. But because children's race is often consistent with the mother's racial identification, we placed priority on adult females' race. For consistency, we did the same for families without children. In aggregating the sample, we selected the racial classification for the first-encountered adult female, adult male, female child, and male child, and our final family racial classification placed priority on racial identity in this order. If an adult female was present, our family race label reflects that person's race (or the race of the first adult female encountered in that family). If no adult female was present, our race variable reflects the first adult male encountered, and so on.

13. For example, a poor single mother with three children yields one poor family but three poor children.

14. Our analysis probably underestimates the effect of employment. It does not take into account the benefits of expansions in the Earned Income Tax Credit.

15. It is important to remember that eliminating racial and ethnic disparities in work and family will not completely end racial and ethnic economic inequality. These two factors are only part of the explanation and, as such, we must continue to look for additional explanations (e.g., low pay, discrimination).

\section{REFERENCES}

Barnes, J. S., \& Bennett, C. E. (2002). The Asian population, 2000. Census 2000 Brief 01-16. Washington, DC: U.S. Census Bureau.

Bauman, K. J. (1999). Shifting family definitions: The effect of cohabitation and other nonfamily household relationships on measures of poverty. Demography, 36, 315-325.

Bianchi, S. M. (1999). Feminization and juvenilization of poverty: Trends, relative risks, causes, and consequences. Annual Review of Sociology, 25, 307-333.

Cancian, M., \& Reed, D. (2002). Changes in family structure: Implications for poverty and related policy. In S. Danziger \& R. Haveman (Eds.), Understanding poverty (pp. 69-96). New York: Harvard University Press and Russell Sage.

Carlson, M., \& Danziger, S. (1999). Cohabitation and the measurement of child poverty. Review of Income and Wealth, 45, 179-191.

Crowley, M., Lichter, D. T., \& Qian, Z. C. (2006). Beyond gateway cities: Economic restructuring and poverty among Mexican immigrant families and children. Family Relations, 55(3), 345-360. 
Danziger, S., \& Gottschalk, P. (2004). Diverging fortunes: Trends in poverty and inequality. The America People Series. Washington, DC: Population Reference Bureau and Russell Sage.

Duncan, G. J., \& Brooks-Gunn, J. (Eds.). (1997). Consequences of growing up poor. New York: Russell Sage.

Eggebeen, D. J., \& Lichter, D. T. (1991). Race, family structure, and changing poverty among American children. American Sociological Review, 56, $801-817$.

Eliason, S. (2002). The categorical data analysis system. Retrieved from http://www.soc.umn.edu/ eliason/CDAS.htm

Gibson, C., \& Jung, K. (2002). Historical census statistics on population totals by race, 1790 to 1990, and by Hispanic origin, 1970 to 1990, for the United States, regions, divisions, and states. Working Paper No. 56. Washington, DC: U.S. Census Bureau.

Gottschalk, P. (1997). Is the correlation in welfare participation across generations spurious? Journal of Public Economics, 63, 1-25.

Gottschalk, P., \& Danziger, S. (1993). Family structure, family size, and family income: Accounting for changes in the economic well-being of children, 1968-1986. In S. Danziger \& P. Gottschalk (Eds.), Uneven tides: Rising inequality in America (pp. 167-193). New York: Russell Sage.

Grieco, E. M., \& Cassady, R. C. (2001). Overview of race and Hispanic origin. Census 2000 Brief 01-1. Washington, DC: U.S. Census Bureau.

Gunderson, C., \& Ziliak, J. P. (2004). Poverty and macroeconomic performance across space, race, and family structure. Demography, 41, 61-86.

Hernandez, D. J. (2004). Demographic change and the life circumstances of immigrant families. Future of Children, 14, 17-47.

Iceland, J. (2003). Why poverty remains high: The role of income growth, economic inequality, and changes in family structure, 1949-1999. Demography, 40, 499-519.

Iceland, J., Short, K., Garner, T. I., \& Johnson, D. (2001). Are children worse off? Evaluating well-being using a new (and improved) measure of poverty. Journal of Human Resources, 36, 398-412.

Jensen, L., \& Chitose, Y. (1994). Today's second generation: Evidence from the 1990 U.S. census. International Migration Review, 28, 714-735.

Lerman, R. I. (1996). The impact of the changing U.S. family structure on child poverty and income inequality. Economica, 63, S119-S139.

Lichter, D. T. (1997). Poverty and inequality among children. Annual Review of Sociology, 23, 121-145.

Lichter, D. T., \& Crowley, M. L. (2002). Poverty in America: Beyond welfare reform. Population Bulletin, 57(June), 1-36.

Lichter, D. T., \& Crowley, M. L. (2004). Welfare reform and child poverty: Effects of maternal employment, marriage, and cohabitation. Social Science Research, 33, $385-408$.

Lichter, D. T., \& Eggebeen, D. J. (1993). Rich kids, poor kids: Changing income inequality among American children. Social Forces, 73, 761-780.

Lichter, D. T., \& Landale, N. S. (1995). Parental work, family structure, and poverty among Latino children. Journal of Marriage and the Family, 57, 346-354.

Lichter, D. T., \& Qian, Z. C. (2004). Marriage and family in a multiracial society. The American People Series. Washington, DC, and New York: Population Reference Bureau and Russell Sage. 
Lichter, D. T., Qian, Z. C, \& Crowley, M. L. (2005). Child poverty among racial minorities and immigrants: Explaining trends and differentials. Social Science Quarterly, 86, 1037-1059.

Manning, W. D., \& Brown, S. (2006). Children's economic well-being in married and cohabiting parent families. Journal of Marriage and Family, 68, 345-362.

Manning, W. D., \& Lichter, D. T. (1996). Parental cohabitation and children's economic well-being. Journal of Marriage and the Family, 58, 998-1010.

McLanahan, S. (2004). Diverging destinies: How children are faring under the second demographic transition. Demography, 41, 607-627.

Moffitt, R. A. (2002). From welfare to work: What the evidence shows. Policy Brief No. 13, January. Welfare Reform and Beyond. Washington, DC: Brookings Institution.

Rainwater, L., \& Smeeding, T. M. (2004). Poor kids in a rich country. Hoboken, NJ: Wiley.

Ruggles, S., Sobek, M., Alexander, T., Fitch, C. A., Goeken, R., Hall, P. K., et al. (2003). Integrated public use microdata series: Version 3.0. Minneapolis: Historical Census Projects, University of Minnesota.

Thomas, A., \& Sawhill, I. (2002). For richer or for poorer: Marriage as an antipoverty strategy. Journal of Policy Analysis and Management, 21, 587-599.

Thomas A., \& Sawhill, I. (2005). For love and money? The impact of family structure on family income. Future of Children, 15, 57-74.

U.S. Census Bureau. (2007a). History poverty tables. Table 3. Retrieved May 23, 2007, from http://www.census.gov/hhes/www/poverty/histpov/hstpov3.html

U.S. Census Bureau. (2007b). History poverty tables. Table 10. Retrieved May 23, 2007, from http://www.census.gov/hhes/www/poverty/histpov/hstpov10.html

U.S. Census Bureau. (2007c). Historical income tables-Families. Retrieved May 23, 2007, from http://www.census.gov/hhes/www/income/histinc/f03ar.html

U.S. Census Bureau. (2007d). Poverty thresholds. Retrieved May 23, 2007, from http://www.census.gov/hhes/www/poverty/histpov/hstpov1.html

Van Hook, J., Brown, S. L., \& Kwenda, M. N. (2004). A decomposition of trends in poverty among children of immigrants. Demography 41, 649-670.

Zedlewski, S., Clark, S., Meier, E., \& Watson, K. (1996). Potential Effects of Congressional welfare reform legislation on family incomes. Washington, DC: Urban Institute Press. 